\title{
Factors determining students' learning creativity in SMPN 9 Surakarta
}

\author{
Ayu Nabila Akifah Noor \\ IAIN Surakarta \\ nabila.akifa@yahoo.com
}

DOI: 10.18326/mudarrisa.v9i1.120-143

\begin{abstract}
The research aims at finding out the determinant factors of: 1) students' learning creativity; 2) school quality; 3) students' personality; 4) the correlation between school quality with the students' learning creativity; 5 ) the correlation between students' personality with students' learning creativity; and 6) the correlation between school qualities with students' personality. The data used data were derived from VIII students of SMP Negeri 9 Surakarta. The sample was 161 students out of 277 students of the population. The sample were from 9 classes and determined by proporsional random sampling technique. The data gathered thorugh questionnaire, measuring the students' learning creativity, the school quality, and the students' personality. The analysis employed LISREL PROGRAM of 8.54 version. The results of the research showed that:1) there were five determinant factors of learning creativity, namely sensitivity toward problem, the fluency in producing a new idea, the flexibelity in expressing solution, the originality in formulating the idea, and the detail in analyzing the idea; 2) there were seven determinant factors of school quality, namely teacher quality, teaching quality, quality of administration services, students' commitments, parents support, resources accessibility, and learning comfort; 3) there were eight determinant factors of students' personality, namely self confident, initiative, competitive, adaptive, responsive, challenge lover, risk taker, and persistency; 4) there was a positive and significant correlation between school quality and students' personality; 5) there was positive
\end{abstract}


but not significant correlation between school quality and students' learning creativity; and 6) there was positive and not significant correlation between students' personality and students' learning creativity.

Keywords: determinant factors, learning creativity, junior high school

\begin{abstract}
Abstrak
Penelitian ini bertujuan untuk menemukan faktor penentu:1) kreativitas belajar siswa; 2) kualitas sekolah; 3) personalitas siswa; 3) hubungan kualitas sekolah dengan kreativitas belajar; 4) hubungan personalitas dengan kreativitas belajar; (5) hubungan kualitas sekolah dengan personalitas.Data bersumber dari siswa kelas VIII SMP Negeri 9 di Surakarta. Populasi penelitian adalah siswa kelas VIII berjumlah 277 siswa. Penentuan ukuran sampel menggunakan Tabel Isaac-Michael sejumlah 161 siswa yang terbagi dalam 9 kelas. Pengambilan sampel menggunakanproportional random sampling. Teknik pengumpulan data menggunakan angket dengan mengukur indikator dari 3 variabel yakni kreativitas belajar, kualitas sekolah, dan personalitas. Analisis data menggunakan Program LISREL Versi 8.54. Hasil penelitian menunjukkan bahwa: 1) lima faktor penentu kreativitas belajar yakni sensitivitas terhadap masalah, kelancaran menghasilkan gagasan baru, keluwesan mengungkapkan solusi, keaslian merumuskan gagasan, dan kerincian menguraikan gagasan; 2) ada tujuh faktor penentu kualitas sekolah yakni kualitas guru, kualitas pengajaran, kualitas pelayanan administrasi, komitmen siswa, dukungan orangtua, aksesibilitas sumber, dan kenyamanan belajar; 3) ada delapan faktor penentu personalitas siswa yakni percaya diri, memiliki inisiatif, kompetitif, adaptif, responsif, menyukai tantangan baru, senang menghadapi risiko, dan memiliki daya bangkit; 4) ada hubungan yang positif dan signifikan antara kualitas sekolah dengan personalitas siswa; 5) ada hubungan yang positif dan tidak signifikan antara kualitas sekolah dengan kreativitas belajar siswa; 6) ada hubungan positif dan tidak signifikan antara personalitas dan kreativitas belajar siswa.
\end{abstract}

Kata kunci: faktor penentu, kreativitas belajar, sekolah menengah pertama 


\section{Introduction}

The first article of UU no 20 of 2003 on National Education System states that education is an effort of human to develop their potentials through the learning processes. Those potentials cover the ability to see, hear, feel, think, and act (Ministry of National Education 2003: 2). Article 17 in the other hand explains that junior high school (SMP) is the level of basic education underlying the next level of education, that is senior high (SMU) (UU No.20 2003 on National Education System, article 17). Therefore junior high school is a very strategic education to form student personality. In other words, the formation of basic attitudes and behaviors is basic necessity. Learning creativity is one part of basic behavior that serves to develop students' skills, especially when students enter the next level of education.

Guilford (Kaufman \& Sternberg, 2006: 15) states that creativity consists of 4 general categories: fluency, flexibility, originality, and elaboration. While Zhang \& Sternberg (Shi, Lu, Dai, \& Lin, 2013: 1) say that creativity refers to freedom, inquisitive, imaginative, and challenging. In detail, Zhou, Shen, Wang, Neber \& Johji (2013: 1) argue that creative students are characterized by imaginative, original, curiosity, and desire to try something new. Furthermore Urban (1996: 146) asserts that the characteristics of a creative person are person who has fluency in generating ideas, flexibility in expressing problem solving, originality in composing ideas, formulating ideas, and being able to elaborate ideas in details. 
Baron (Rotherngerg \& Hausman, 1976: 189) states that students are called creative if they could create something new and original. Colangelo \& Davis (1991: 368) says that a person who thinks creatively is characterized by being sensitive to problems, fluency, flexibility, authenticity, and detail in expressing ideas. In line with the above opinion, Treffinger (1980: 15-16) claims creative person tends to be smooth, flexible, authentic and clear in delivering the ideas which are arranged in detail, thorough and neat. Thus it is understood that creative students are students who have the ability to give birth to something new both in the form of ideas and concrete works, which are relatively different from those existed before, to be sensitive to problems, shortcomings, inequalities in knowledge, non-existent elements, disharmony and so forth.

Creativity development is needed to develop student competence. Competence according to Boud \& Solomon (2001: 6) refers to the ability of students in completing tasks that have been given to them. If the student has been able to complete the assigned tasks, $\mathrm{s} / \mathrm{he}$ is competent in that task. According to Schippers \& Patriana (1994: 23-25), a graduate school is considered to have competences if he already has a qualification of personality. Meanwhile, according to Campbell \& Panzano (1985: 21) that aspects of the quality of educational graduates include interpersonal skills, confidence in doing the task, and work independently. This concept is closely related to personality. This means that someone's personality affects his choice in determining the quality of school. Thus it is possible to see the relation between of learning creativity, school 
quality, and student personality. Therefore these three variables become very important factors to be studied.

Seeing from the data source, this research includes ex post facto research, because this research does not treat or condition the variables. Meanwhile, when viewed from its form, this research belongs to correlational research, because this study examines and reveals the relationship between research variables. When viewed from data collection techniques, this research is a survey research.

The problem studied by this research is about the determinants of students' learning creativity. This learning creativity is the key to students' success in developing themselves, both at school and in the community. Learning creativity will increase not only solely influenced by its indicators but also by other latent variables along with indicators of each latent variable. In addition to study, the relationship between latent variables could never be less important, because the creativity of learning cannot be developed independently, but it can be done by developing latent variables that have a strong relationship. Therefore, this study has two objectives: 1) to find out the factors that determine the creativity of learning, school quality and the personality of the students of SMP Negeri 9 Surakarta; 2) to find out how strong the relationship between school quality and learning creativity, student personality and student learning creativity, also school quality and the personality of SMP Negeri 9 Surakarta.

The focus of this article is directed to both the main objectives of the study above whether the determinants or the strength of the 
relationship between these determinants. And to get maximum research result, this article describes the research by describing the research methods implemented in the discussion, which is supported by understanding other researches to achieve expected results and it can be seen form the conclusions of this results.

\section{Research methods}

This research was conducted in SMP Negeri 9 Surakarta. This research viewed from the source data is ex post facto research, because this research does not treat or condition the variables. Viewed from its form, this research is correlational research, because this study examines and reveals the relationship between research variables. If it is viewed from data collection techniques, this research is a survey research.

This study uses data sources from eight grade students of SMP Negeri 9 Surakarta with 277 students as the population. Using proportional random sampling technique and Sample Size Table Isaac and Michael (1981: 193), the sample research is 161 students. There are several variables involved School Quality as exogenous variable and Student's Personality and Creativity Student Learning as endogenous variable.

The data were collected through questionnaire. This questionnaire is used to measure three variables namely: 1) Learning Creativity; 2) School Quality; 3) Student's personalities. There were 25 items measuring learning creativity, 43 items for school quality and 46 items for personality. 
In answering the problems, this research employed confirmatory factor analysis, and path analysis. Confirmatory analysis aims at testing the correctness of the measurement model, while path analysis is used to test the correctness of the structural model. Both of these analyzes have been provided by the Lisrel Model Analysis Program. The Lisrel model consists of measurement models and structural models. The measurement model describes the latent variables indicated by the observed variable; while the structural model describes the relationship between latent variables (Joreskog \& Sorbom, 1996: 1).

This study was conducted using Lisrel Program 8.54, which is the most widespread statistical software among researchers and practitioners. This program is chosen because of its ability in identifying the relationship between the complex variables; allowing the researcher to get the comprehensive and high-accurate pictures of the case in either direct or indirect relationships. However, this software is none without drawbacks. It could not process the data in small number. For example, when researchers have less than 200 samples with a complex model, sometimes the estimation results do not match the expectations of the researcher. This research, again, used 277 students as the population, implying the negative impacts mentioned before could be avoided.

\section{Measurement model}

The measurement models in the process of obtaining and finding the results of the study consist of models for creativity measurement, school quality measurement model, and personality measurement model. 


\section{Learning creativity}

Findings related to the measurement model can be presented on the following figure:

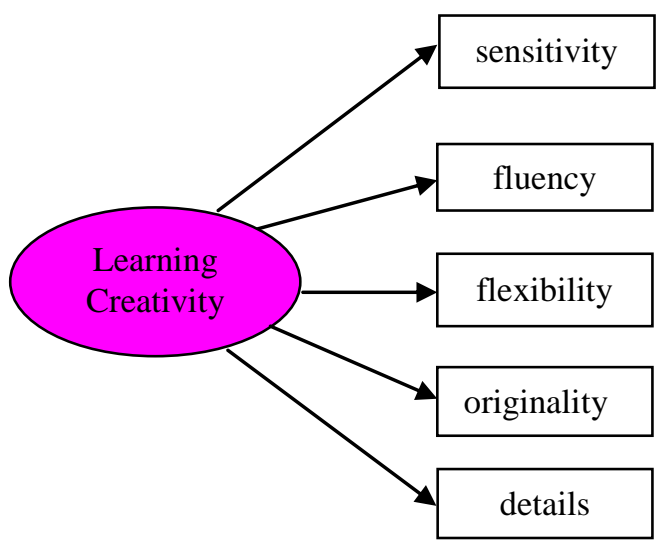

Figure 1. The learning creativity measurement model

The summary of the measurement model test results can be presented in Table 1 as follows.

Table 1. Summary of test results on learning creativity measurement model

\begin{tabular}{clcccl}
\hline No & $\begin{array}{l}\text { Manifest } \\
\text { Variable }\end{array}$ & $\begin{array}{c}\text { Relation } \\
\text { Coefficient }\end{array}$ & $\begin{array}{c}\text { Measurement } \\
\text { Mistake }\end{array}$ & $t$-Value & Conclusion \\
\hline 1 & Sensitivity & 0.461 & 0.788 & - & Valid \\
2 & Fluency & 0.507 & 0.743 & $2.614>1.96$ & Valid \\
3 & Flexibility & 0.389 & 0.849 & $2.855>1.96$ & Valid \\
4 & Originality & 0.600 & 0.640 & $2.738>1.96$ & Valid \\
5 & Details & 0.334 & 0.888 & $2.523>1.96$ & Valid \\
\hline
\end{tabular}

Table 1 above shows that sensitivity, fluency, flexibility, originality, and detail as the determinant factors for creativity are valid. It is shown by the value of t-count all indicators are > 1.96. Determination of the 
validity of the sensitivity indicator is done by means of interpolation by comparing it with the t-value of other indicators.

\section{School quality}

The empirical model findings relating to the school quality measurement model can be presented below

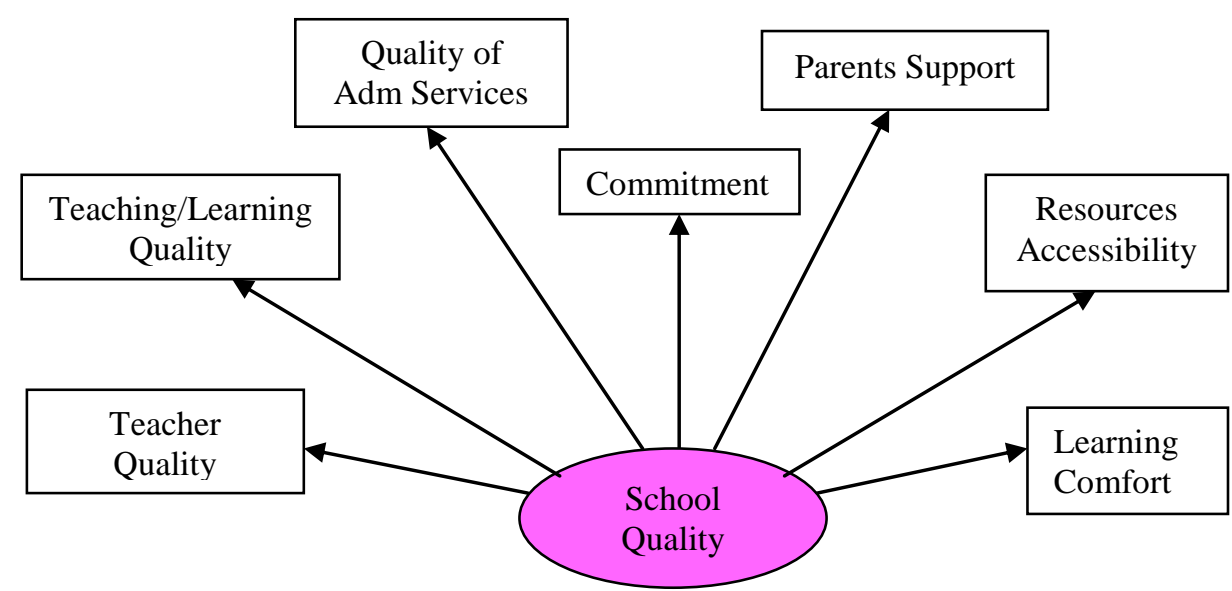

Figure 2. School quality measurement model and parameter value

A summary of the test results of the measurement model can be presented in Table 2 .

Table 2. Summary of test for school qualities measurement model

\begin{tabular}{|c|c|c|c|c|c|}
\hline No & $\begin{array}{l}\text { Manifest } \\
\text { Variable }\end{array}$ & $\begin{array}{c}\text { Relation } \\
\text { Coefficient }\end{array}$ & $\begin{array}{l}\text { Measurement } \\
\text { Mistake }\end{array}$ & t-Value & Conclusion \\
\hline 1 & $\begin{array}{l}\text { Learning } \\
\text { comfort }\end{array}$ & 0.599 & 0.641 & - & $\begin{array}{l}\text { Valid } \\
\text { (interpolated) }\end{array}$ \\
\hline 2 & $\begin{array}{l}\text { Teaching } \\
\text { quality }\end{array}$ & 0.534 & 0.714 & $5.786>1.96$ & Valid \\
\hline 3 & $\begin{array}{l}\text { Teachers } \\
\text { quality }\end{array}$ & 0.719 & 0.483 & $6.607>1.96$ & Valid \\
\hline 4 & $\begin{array}{l}\text { Quality of } \\
\text { Administrative } \\
\text { services }\end{array}$ & 0.626 & 0.608 & $6.026>1.96$ & Valid \\
\hline
\end{tabular}




\begin{tabular}{clcccc}
\hline 5 & $\begin{array}{l}\text { Resources } \\
\text { accessibility }\end{array}$ & 0.651 & 0.577 & $5.527>1.96$ & Valid \\
6 & $\begin{array}{l}\text { Parents } \\
\text { support }\end{array}$ & 0.296 & 0.912 & $2.626>1.96$ & Valid \\
7 & $\begin{array}{l}\text { Students } \\
\text { commitments }\end{array}$ & 0.644 & 0.585 & $6.334>1.96$ & Valid \\
\hline
\end{tabular}

Table 2 above shows that learning comfort, teaching quality, teachers' quality, quality of administrative services, resources accessibility, parents' supports, and students' commitment are valid. It is shown by the value of t-count is bigger that 1.96 applied to all variables. The determination of the validity of the convenience indicator is done by means of interpolation by comparing it with the t-value of the other indicators.

\section{Personality}

The findings of the empirical model relating to the measurement model of personality can be presented in Figure 3 below.

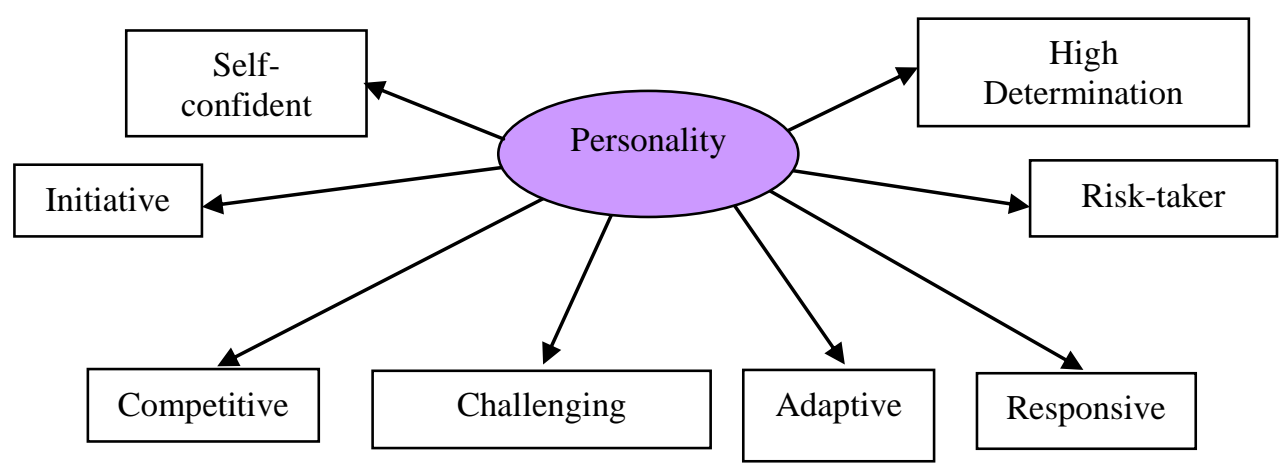

Figure 3. Measurement model of personality and parameter value

A summary of the test results of the measurement model can be presented in Table 3. 
Mudarrisa: Jurnal Kajian Pendidikan Islam, Vol. 9, No. 1, 2017: 120-143

Table 3. Summary of the test results for personality measurement model

\begin{tabular}{clcccl}
\hline No & $\begin{array}{c}\text { Manifest } \\
\text { Variable }\end{array}$ & $\begin{array}{c}\text { Relation } \\
\text { Coefficient }\end{array}$ & $\begin{array}{c}\text { Measurement } \\
\text { Mistake }\end{array}$ & $t$-Value & Conclusion \\
\hline 1 & Self-confident & 0.598 & 0.646 & - & Valid \\
(interpolated) \\
2 & Initiative & 0.674 & 0.546 & $8.129>1.96$ & Valid \\
3 & Fast Worker & -0.115 & 0.987 & $-1.078<1.96$ & Invalid \\
4 & Competitive & 0.398 & 0.842 & $3.580>1.96$ & Valid \\
5 & On time & 0.149 & 0.978 & $1.166<1.96$ & Invalid \\
6 & Adaptive & 0.492 & 0.758 & $3.371>1.96$ & Valid \\
7 & Responsive & 0.600 & 0.640 & $4.792>1.96$ & Valid \\
8 & Challenge lover & 0.486 & 0.764 & $5.346>1.96$ & Valid \\
9 & Risk Taker & 0.605 & 0.633 & $6.173>1.96$ & Valid \\
10 & Persistent & 0.358 & 0.872 & $2.702>1.96$ & Valid \\
\hline
\end{tabular}

Table 3 above shows that there are 8 out of 10 valid variables putting aside 2 invalid variables. The eight valid indicators are self-confident, initiative, competitive, adaptive, responsive, challenge lover, risk taker, and persistent. The 2 invalid indicators are fast worker and on time. It is indicated by the value of its t-count. Further, in determining the validity of self-confident indicator, inter-polarity was used i.e. comparing it with other t-value indicators.

\section{Structural model}

The findings of the study related to the structural model in the process of obtaining and finding the results of the research are as presented in Figure 4 and Table 4.

Table 4. Summary of test results on relationship between latent variables

\begin{tabular}{lccc}
\hline \multicolumn{1}{c}{ Latent variable } & Coefficient & t- Value & Conclusion \\
\hline School Quality - Creativity & $\gamma=0.220$ & $1.774<1.96(5 \%)$ & Insignificant \\
Personality - Creativity & $\beta=0.280$ & $1.613<1.96(5 \%)$ & Insignificant \\
School Quality - Personality & $\gamma=0.282$ & $2.341>1.96(5 \%)$ & Insignificant \\
\hline
\end{tabular}




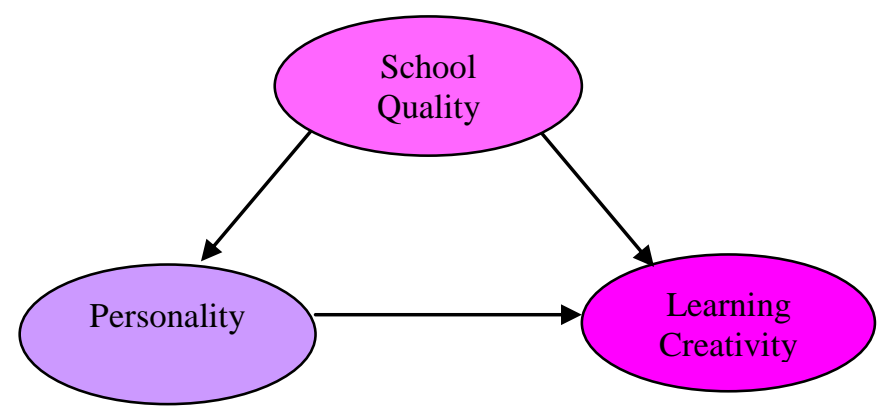

Figure 4. Structural models between learning creativity, school quality, and personalities

Table 4 shows that (1) the relationship between learning quality and learning creativity is not significant at $\gamma=0.220$ and $\mathrm{t}$-value $=1.774$ $<1.96$ (5\% significance level); (2) the relationship between personality and creativity of learning is not significant at $\beta=0,280$ and $\mathrm{t}$-value $=$ $1.613<1.96$ (at significance level 5\%); and (3) relationship between school quality with personality is significant at $\gamma=0.282$ and $\mathrm{t}$-value $=$ $2.341>1.96$ (at 5\% significance level).

\section{Research results on measurement model and structural model}

Discussion of research results relating to measurement models and structural models may be described as follows;

\section{Learning creativity}

As mentioned before learning creativity has five indicators namely: 1) sensitivity to the problem; 2) fluency in generating new ideas; 3) flexibility in expressing solution; 4) originality in formulating ideas; and 5) detail in elaborating ideas. The large contribution of learning creativity to the indicator can be seen in the measurement equation and its 
Mudarrisa: Jurnal Kajian Pendidikan Islam, Vol. 9, No. 1, 2017: 120-143

covariance matrix. The summary form of the analysis results are as presented in Table 5.

Table 5. Summary of measurement and matrix of learning creativity covariance

\begin{tabular}{llccc}
\hline Variable & \multicolumn{1}{c}{ Indicator } & $\begin{array}{c}\text { Error } \\
\text { Variance }\end{array}$ & $\mathrm{R}^{2}$ & $\begin{array}{c}\text { Total } \\
\text { Variance }\end{array}$ \\
\hline Learning & Sensitivity to problems & 2.541 & 0.212 & 3.226 \\
Creativity & Fluency in generating ideas & 6.060 & 0.257 & 8.158 \\
& Flexibility in expressing & 3.498 & 0.151 & 4.120 \\
& solutions & & & \\
& Originality in formulating ideas & 4.046 & 0.360 & 6.325 \\
& Details in elaborating ideas & 3.243 & 0.112 & 3.650 \\
\hline
\end{tabular}

Sensitivity to problems

The Error Variance value of 2.541 is smaller than Total Variance of 3.226 indicating that learning creativity can adequately explain the sensitivity towards problems. It is supported by $\mathrm{R}^{2}=0.212$ illustrating that creativity affects the sensitivity toward problems for $21.2 \%$. The number might be small, but it proves that sensitivity development becomes crucial in developing students' learning creativity.

Fluency in generating new ideas

The Error Variance value of 6.060 is smaller than Total Variance of 8.158 indicating that learning creativity can adequately explain the fluency in generating new ideas. It is supported by $\mathrm{R}^{2}=0.257$ meaning that creativity suggests $25.7 \%$ of fluency in generating new ideas. If the fluency in generating ideas increases, the students' learning creativity increases as well.

Flexibility in expressing solution

The Error Variance value of 3.498 is smaller than Total Variance of 
4.120 indicating that learning creativity could explain the flexibility in expressing the solution. It is supported by $\mathrm{R}^{2}=0.151$ meaning creativity contributes $15.1 \%$ in students' flexibility in expressing solution. The number is small, but still teacher is recommended to develop students' flexibility in expressing solution.

Originality in formulating ideas

The Error Variance value of 4.046 is smaller than Total Variance of 6.325 indicating that learning creativity could explain the variety of students' originality in formulating ideas. It is supported by $\mathrm{R}^{2}=0.360$, meaning creativity contributes $36.0 \%$ in students' originality in formulating ideas. Improving students' originality in formulating ideas should become priority to be developed; this is due to the fact that the number is higher than other indicators.

Details in elaborating ideas

The Error Variance value of 3.243 is smaller than Total Variance of 3.650 indicating that learning creativity could explain the details in elaborating ideas, but in small number. It is supported by $\mathrm{R}^{2}=0.112$ illustrating that it gives $11.2 \%$ in students ability to give details in elaborating ideas. Even though the percentage is small, teacher should develop students' ability in detailing the ideas they have.

\section{School quality}

School quality embraces 7 indicators, namely (1) teacher quality; (2) the teaching quality; (3) quality of administrative services; (4) student commitment; (5) parents support; (6) source accessibility; and (7) learning comfort. The amount of school quality contribution to the 
indicators can be seen in the measurement equation and its covariance matrix. The summary is presented in Table 6 below

Table 6. Summary of equation of measurement and covariance matrices on school quality

\begin{tabular}{llccc}
\hline Variable & \multicolumn{1}{c}{ Indicators } & $\begin{array}{c}\text { Error } \\
\text { Variance }\end{array}$ & $\mathrm{R}^{2}$ & $\begin{array}{c}\text { Total } \\
\text { Variance }\end{array}$ \\
\hline School & Teacher Quality & 5.150 & 0.517 & 10.665 \\
Quality & Teaching/Learning Quality & 7.674 & 0.286 & 10.742 \\
& Quality of administrative Service & 8.525 & 0.392 & 14.025 \\
& Students Commitment & 4.607 & 0.415 & 7.873 \\
& Parent Support & 5.260 & 0.0877 & 5.765 \\
& Source Accessibility & 7.861 & 0.423 & 13.628 \\
& Learning comfort & 9.477 & 0.359 & 14.788 \\
\hline
\end{tabular}

\section{Teacher quality}

The error variance value of 5.150 is smaller than total variance of 10.665 indicating that school quality determines teacher quality with high score. It is supported by $\mathrm{R}^{2}=0.517$ meaning that the school quality suggest at $51.7 \%$ on teacher quality. The value has already been high, but the management or the headmaster should still improve the teacher competences by giving chances to study in higher level and series of workshops. This matters since the school quality contributes at the highest score to teacher quality.

\section{Teaching/learning quality}

The error variance value of 7.674 is smaller than total variance of 10.742 indicating that school quality determines teaching quality with relative small amount. It is supported by $\mathrm{R}^{2}=0.286$ which means the quality of schools can contribute to the quality of teaching by $28.6 \%$. Although the contribution is relatively small, school managers, especially principals, still need to improve the quality of teaching for their teachers, so that in 
the learning process can improve the quality possessed by a teacher. It can be said that if the methods used by the teachers are varied, students will experience various learning processes.

Quality of administrative services

The error variance value of 8.525 is smaller than total variance of 14.025 indicating that school quality determines the quality of administrative services at adequate level. It is supported by $\mathrm{R}^{2}=0.392$ which means the quality of schools can contribute to the quality of administrative services of $39.2 \%$. Contribution of $39.2 \%$ is included at quite adequate level. Although the contribution is not too high but the school management needs to improve the quality of administrative services through the control of documents and archives and services to students.

\section{Student commitment}

The error variance value 4.607 is smaller than total variance of 7.873 indicating that school quality determines students' commitment at high level. It is supported by $\mathrm{R}^{2}=0.415$ which means the quality of the school can contribute to the commitment of students by $41.5 \%$. This number is quite high. This means that school managers need to focus on the mental development of students that they will have high commitment. As what happens with teacher quality, the improvement of students' commitment is likely to increase school quality compared to other indicators.

\section{Parent support}

The error variance value 5.260 is smaller than total variance of 5.765 indicating that school quality affects parents support at low level. It is supported by $\mathrm{R}^{2}=0.877$ means the quality of schools can contribute to 
parent support at $8.77 \%$. Given this small number, the school should still maintain close relationship with the parents of the students. Schools without the support of parents will experience obstacles in fostering student developmental education.

Resources accessibility

The error variance value 7.861 is smaller than total variance of 13.628 indicating that school quality can explain the source accessibility variance quite high at high level. It is supported by $R^{2}=0.423$ which means the quality of the school can contribute to the accessibility of the source of $42.3 \%$. This means that school managers need to focus on the development of educational infrastructure facilities such as libraries, computer laboratories, and learning media. Increased access to these resources can significantly improve school quality, as well as improvements in teacher quality, and student commitment.

\section{Learning comfort}

The error variance value 9.477 is smaller than total variance of 14.788 indicating that school quality can sufficiently explain the learning comfort variance. It is supported by $\mathrm{R}^{2}=0.359$ meaning that school quality contributes at $35.9 \%$. If the learning environment is comfortable, it could be significant factors improving students' achievements.

\section{Personality}

Personality measures 10 indicators, namely: 1) self-confidence, 2) initiative; 3) fast work; 4) competitive; 5) value the time; 6) adaptive; 7) responsive; 8) challenge lover; 9) risk taker; and 10) persistency. The 
amount of school quality contribution to those indicators can be seen in the equation and its covariance matrix below at Table 7 .

Table 7. Summary of measurement equations and matrices of personality covariance

\begin{tabular}{clccc}
\hline Variable & \multicolumn{1}{c}{ Indicators } & $\begin{array}{c}\text { Error } \\
\text { Variance }\end{array}$ & $\mathrm{R}^{2}$ & $\begin{array}{c}\text { Variance } \\
\text { Total }\end{array}$ \\
\hline Personalities & Self-Confident & 2.616 & 0.354 & 4.047 \\
& Initiative & 3.525 & 0.454 & 6.457 \\
& Fast Worker & 7.852 & 0.0132 & 8.502 \\
& Competitive & 3.500 & 0.158 & 4.400 \\
& Value for Time & 3.346 & 0.0222 & 3.422 \\
& Adaptive & 5.682 & 0.242 & 7.494 \\
& Responsive & 1.998 & 0.360 & 3.123 \\
& Challenge lover & 3.379 & 0.236 & 4.897 \\
& Risk Taker & 5.715 & 0.367 & 9.030 \\
& Persistency & 7.389 & 0.128 & 8.474 \\
\hline
\end{tabular}

Self confidence

The Error Variance value 2.616 is smaller than Total Variance of 4.047 indicating that personality is highly affect self-confidence. It is supported by $\mathrm{R}^{2}=0.354$ meaning that personality can contribute to confidence at $35.4 \%$. The school needs to develop students' self-confidence by implementing certain teaching models which give students to improve their confidence.

\section{Initiative}

The Error Variance value 3.525 is smaller than Total Variance of 6457 indicating that personality averagely affects initiative. It is supported by $\mathrm{R}^{2}=0.454$ meaning that personality contributes to the initiative by $45.4 \%$. The school needs to focus to develop personalities by improving students' initiatives through some sort of tasks giving students chances to take initiation in doing the tasks. 
Fast working

The Error Variance value 7.852 is smaller than Total Variance of 8.502 indicating that personality quite affects fast working. It is supported by $\mathrm{R}^{2}=0.0132$ means personality can contribute to fast working by $1.32 \%$. Although the development of personality is not determined by the factors of fast working, teachers still need to nurture their students to complete the tasks based on the time allotted.

\section{Competitive}

The Error Variance value 3.500 is smaller than Total Variance of 4.400 indicating that personality can explain competitive variance at low level. It is supported by $\mathrm{R}^{2}=0.158$ which means the personality can contribute to the competitive of $15.8 \%$. Although personality contributes to competitive factors in low level, teachers still need to develop a competitive mentality for students. The school needs to create competitive graduate since the future life is more complex and more competitive.

\section{Value for the time}

The Error Variance value 3.346 is smaller than Total Variance of 3.422 indicating that personality can explain students' value for the time at low level. It is supported by $\mathrm{R}^{2}=0.0222$ which means that personality can contribute to the valuation of time by $2.22 \%$. Although the contribution is quite small, still teacher has to teach students on how to value the time, to be punctual, so that students could work effectively and efficiently.

\section{Adaptive}

The Error Variance value 5.682 is smaller than Total Variance of 7.494 
indicating that personality can explain students' adaptive ability at adequate level. It is supported by $R^{2}=0.242$ which means the personality can contribute to the adaptive of $24.2 \%$. The percentage of this contribution is neither too high nor too low. Teachers need to improve students' adaptive power in their relationships. If the student has high adaptive ability, then it is expected that they will succeed in career or at work.

Responsive

The Error Variance value 1.998 is smaller than Total Variance of 3.123 indicating that personality can explain responsive variance at quite high level. It is supported by $\mathrm{R}^{2}=0.360$ which means the personality can contribute to the responsiveness of $36.0 \%$. High level of responsiveness will contribute significantly to the student's personality. For that, teachers need to do coaching in terms of sensitivity to the problems faced.

\section{Challenge lover}

The Error Variance value 3.379 is smaller than Total Variance of 4.897 indicating that personality can explain the love for challenge at an adequate level. It is supported by $\mathrm{R}^{2}=0.236$ meaning that personality contributes to the feeling of keen for challenge at $23.6 \%$. Although it is not a priority in developing student personality, students could be trained to love the challenges because it could build their strong mentality in facing future life.

Risk-taker

The Error Variance value 5.715 is smaller than Total Variance of 9.030 indicating that personality can explain the love for challenge at an 
adequate level. It is supported by $\mathrm{R}^{2}=0.367$ meaning that the personality can contribute to love the risks at $36.7 \%$. This number implies that there is the need to focus on the students' personality development. One students love to take the risks, their personalities improve significantly. Persistency

The Error Variance value 7.389 is smaller than Total Variance of 8.473 indicating that personality can explain the persistent feeling at low level. It is supported by $\mathrm{R}^{2}=0.128$ which means that personality contributes to persistent feeling at $12.8 \%$. Though the number is small, persistency needs to be develop somehow to spread positive influence to friends. This will lead them to not easily give up in facing problems they may face.

\section{Structural Model}

The results of the analysis show that (1) there is a positive and insignificant relationship between school quality and learning creativity; (2) there is a positive and significant correlation between school quality and personality; and (3) there is a positive and insignificant relationship between personality and learning creativity. The number of contribution given by latent variables is indicated by the following structural equations and covariance matrices.

Structural similarity:

(1) Creative $=0.194 *$ Person $+0.0789 *$ School Quality, Errorvar. $=0.574, \mathrm{R}^{2}=0.161$

1.613

$(0.0445)$

$(0.272)$

1.774

2.113 
(2) Person $=$

$0.146 *$ K_SKL, Errorvar. $=1.318, \mathrm{R}^{2}=0.0796$

(0.0626)

2.341

2.850

Covariance matrices:

\begin{tabular}{lccc}
\hline & Learning Creativity & Personality & School Quality \\
\hline Learning Creativity & 0.685 & - & - \\
Personality & 0.339 & 1.432 & - \\
School Quality & 0.570 & 0.778 & 5.310 \\
\hline
\end{tabular}

Structural Equation (1) shows that error variance of 0.574 is lower that total variance of 0.685 ; at the $\mathrm{R}^{2}=0.161$. This means that the personality and quality of the school can explain the learning creativity significantly. This is shown also by the value of $R^{2}=0.161$ which means that the personality and quality of the school can contribute to the creativity of learning by $16.1 \%$.

The Structural Equation (2) shows that error variance of 1.318 is lower than total variance of $1.432 ; \mathrm{R}^{2}=0.0796$. This means the quality of the school can explain personality quite significantly. This is shown also by the value of $R^{2}=0.0796$ which means that the quality of the school can contribute to the personality of $7.96 \%$.

\section{Conclusion}

This study concluded that: firstly there were five determinants of learning creativity, namely: sensitivity to problem $(\lambda=0.461)$, fluency in generating new idea $(\lambda=0,507)$, flexibility in expressing solution $(\lambda=$ $0,389)$, originality in formulating idea $(\lambda=0,600)$, and details in 
elaborating idea $(\lambda=0.334)$. Secondly, there were seven determinants of quality of school, they were teacher quality $(\lambda=0,719)$, teaching quality $(\lambda=0,534)$, quality of administrative service $(\lambda=0,626)$, student commitment $(\lambda=0,644)$, parent support $(\lambda=0,296)$, resources accessibility $(\lambda=0,651)$, and learning comfort $(\lambda=0,599)$. Thirdly, there were eight component determining personalities, namely self-confidence $(\lambda=0.598)$, initiative $(\lambda=0.674)$, competitive $(\lambda=0,398)$, adaptive $(\lambda=$ $0,492)$, responsive $(\lambda=0,600)$, challenge lover $(\lambda=0,486)$, risk taker $(\lambda$ $=0,605)$, and persistency $(\lambda=0,358)$. The next was that there was a positive and significant relationship (at level 5\%) between school quality and student's personality. The fifth was that there was a positive and insignificant relationship (at level 5\%) between school quality and student learning creativity. Lastly, there was a positive and insignificant relationship (at level 5\%) between personality and student learning creativity.

\section{References}

Boud, D., \& Solomon, N. (2001). Work-based learning: a new higher education? Ballmoor, Buckingham: SRHE and Open University Press.

Campbell, P. E., \& Panzano, P. (1985). Toward excellence in secondary vocational education elements of program quality. Columbus, Ohio: NCRVE.

Colanggo \& Davis, G. A. (1991). Handbook of gifted education. Boston: Allyn \& Bacon.

Departemen Pendidikan Nasional. (2003). Undang-undang Republik Indonesia No. 20 tahun 2003 tentang sistem pendidikan nasional. Jakarta: DITJENDIKDASMEN. 
Isaac, S. \& Michael, W., B. (1981). Handbook in research and evaluation. San Diego, California: Edits Publisher.

Joreskog, K. G. \& Sorbom, D. (1996). Lisrel 8: user's reference guide. Chicago, IL: Scientific Software International, Inc.

Kaufman, J. C., \& Sternberg, R. C. (2006). The international handbook of creativity. New York: Cambridge University Press.

Rothernberg, A. \& Hausman, C. (1976). The creativity question. Durkham: Duke University Press.

Schippers, U., \& Patriana. (1994). Pendidikan kejuruan di Indonesia. Bandung: Angkasa.

Shi, B., Lu, Y., Dai, D. Y., et. al. Relationships between migration to urban settings and children's creative inclinations. Creative Research Journal Volume 25, Issue 3.

Zhou, J., Shen, J., Wang, X., et. al. (2013). A cross-culture comparison: teachers' conceptualizations of creativity. Retrieved from http://www.tandfonline.com/doi/full/10.1080/10400419.2012.730 006\# preview

Treffinger, D. J. (1980). Encouraging creative learning for the gifted and talented. California: Ventura.

Urban, K. K. (1996). Encouraging and nurturing creativity in school and workplace. Jakarta: Faculty of Psychology UI. 